\title{
The elite exclusion: stratified access and production during the Chinese higher education expansion
}

\author{
Yanqing Ding ${ }^{1,2} \cdot$ Yinduo $\mathrm{Wu}^{1,2} \cdot$ Jin $\mathrm{Yang}^{3} \cdot \mathrm{Xiaoyang} \mathrm{Ye}^{4}$
}

Accepted: 11 January 2021 / Published online: 6 April 2021

(c) The Author(s), under exclusive licence to Springer Nature B.V. part of Springer Nature 2021

\begin{abstract}
This paper presents new evidence on how enrollment expansion affects higher education access and production with a focus on social inequality and institutional stratification. From 1999 to 2012, the world's largest higher education expansion happened in China that annual college enrollment dramatically increased from 1,083,600 to $6,888,300$. We evaluate this exogenous, unprecedented policy using nationally representative student-level survey data and newly available confidential institution-level data. Enrollment expansion, which reduced per-student resources, negatively impacted college quality as measured by value-added on graduates' employment and earnings. The inequality in access between high- and low-SES students and the stratified production between college institutional tiers persisted during expansion.
\end{abstract}

Keywords Higher education policy · Enrollment expansion · College access · Value-added production $\cdot$ Inequality and stratification

\begin{abstract}
We thank Xin Li, Peilin Qiu, Yishu Xu, Yuchen Yang, and Jingyin Zhang for their superb research assistance, the editor, three anonymous reviewers, Stephen DesJardins, Brian McCall, Kevin Stange, Donald Treiman, Rong Wang, Xiaogang Wu, Yu Xie, Fengqiao Yan, Po Yang, and participants at the American Educational Research Association Meeting, China Economics of Education Conference, Peking-Duke Conference on Higher Education, and the Quantitative Methodology Seminar at the University of Michigan for their insightful comments, the Ministry of Education of China and the Institute of Economics of Education at Peking University for providing the data, and the National Natural Science Foundation of China (71673013) for financial support. Please direct all correspondence to Xiaoyang Ye (xiaoyang.ye@brown.edu). Alphabetically equal authorship applies. All errors and omissions are our own.
\end{abstract}

Xiaoyang Ye

xiaoyang.ye@brown.edu; xiaoyang.ye@princeton.edu

1 Institute of Economics of Education, Peking University, Beijing, China

2 Graduate School of Education, Peking University, Beijing, China

3 Institute of Educational Economics and Administration, University of Science and Technology Beijing, Beijing, China

4 School of Public and International Affairs, Princeton University, Princeton 08540, New Jersey, US 


\section{Introduction}

The second half of the twentieth century is an era of higher education expansion that access to college has been greatly increased in nearly every country in the world (Trow, 1972; Schofer \& Meyer, 2005; Shavit et al., 2007; Carnoy et al., 2013). The worldwide average gross enrollment ratio in higher education increased dramatically from $3 \%$ in 1950 to $10 \%$ in 1970 and to $38 \%$ in 2018 . The number of college students increased from 29 million to over 141 million in the world between 1970 and 2006 (Freeman, 2010). While most developed countries entered the mass higher education stage before the new century, many middle- and low-income countries have been largely expanding college enrollment in the past decades (Marginson, 2016a; Özoğlu et al., 2016).

However, how higher education expansion affects educational inequality in access and production remains both theoretically and empirically unclear. On college access, existing literature presents two competing theories. Some researchers argue that expansion is a diversion process of social stratification that working class is diverted to the second-tier universities, while elite institutions remain the bastion of the privileged (Raftery \& Hout, 1993; Lucas, 2001). Despite dramatic higher education expansions as well as various federal and state college-enrollment policies, large racial and socioeconomic gaps persist over decades (Perna et al., 2008). Some others insist that expansion brings the inclusion of higher education that the lower class students obtain more college opportunities for social mobility (Arum et al., 2007). On production (i.e., students' post-college outcomes), as one of the best known evidence in higher education since the seminal work by Weisbrod and Karpoff (1968), we know that college quality substantially improves labor market outcomes and intergenerational social mobility (e.g., Brewer et al., 1999; Black \& Smith, 2004; Zhang, 2005b; Dale \& Krueger, 2014; Chetty et al., 2017), but we know very little about how policy controlled dramatic increases in enrollment would change college production as measured by a college's value-added on students' postgraduation employment and earnings.

This paper presents new evidence on the impacts of enrollment expansion on students' college access and labor market outcomes by exploiting the world's largest higher education expansion policy in China from 1999 to 2012. Similar to the global trend, China increased its annual undergraduate enrollment from 1 million to about 7 million in only thirteen years between 1999 and 2012. The organization of higher education also changed dramatically. The expansion was accompanied by differentiation and stratification that a stable higher education hierarchy comes into being (Li, 2004; Yang \& Wang, 2020), which resulted in five selectivity tiers of higher education institutions, ranging from the top 39 universities to more than 1,000 three-year vocational colleges in the lowest selectivity tier.

This exogenous, unprecedented national expansion policy enables us to credibly answer three research questions: (1) How does enrollment expansion affect access to (elite) college differently between students from high and low SES families? (2) How does enrollment expansion change college production as measured by a college's value-added on students' labor market outcomes? And (3) how do the expansion effects vary between selective and non-selective colleges in a highly institutionally stratified higher education system?

To answer these questions, we combine nationally representative student-level survey data with newly available confidential institution-level data. The National Survey on College Graduates' Employment, conducted by the Institute of Economics of Education at Peking University, surveyed a nationally representative sample of college graduates bi-annually from 2003 to 2013 (sample size $=113,435$ ). This is the only available 
multi-period college graduates' survey data that spanned a long time period during the expansion in China, starting from the first cohort that experienced enrollment expansion. Additionally, we use enrollment and input information on every college from the newly available China Educational Finance Statistics - Postsecondary data from 1998 to 2013, which were provided by the Ministry of Education of China. Using these unique data, this paper presents the first evidence on the differential changes in higher education access, inputs, and production by institutional stratification before and after the expansion policy.

Consistent with theories and the policy practice in other countries (e.g., the recent U.S. enrollment expansion during the Great Recession, Barr \& Turner, 2013), our empirical analyses provide compelling evidence and explanations on the increased inequality and stratification in higher education access, resources, and outcomes during enrollment expansion. This paper makes four contributions to higher education policy research. First, we find evidence of the enlarging unequal access to elite higher education for students from different family backgrounds during the enrollment expansion, which supports the effectively or expanding maintained inequality theory (Lucas, 2001; Alon, 2009). These results speak to a large body of literature on higher education enrollment expansion and access in many countries, for instance, the United States (Taubman et al., 1972; Walters, 1984; Juhn et al., 2005; Barr \& Turner, 2013; Soliz, 2018), France (Deer, 2005), the United Kingdom (Walker \& Zhu, 2008; Boliver, 2011; Devereux \& Fan, 2011), Italy (Bratti et al., 2008; Oppedisano, 2011)), Germany (Reimer \& Pollak, 2010), Turkey (Özoğlu et al., 2016), Brazil (McCowan, 2007; Boliver, 2011; Dias et al., 2011), Ireland (McCoy \& Smyth, 2011), and China (Luo et al., 2018; Ou \& Hou, 2019). In particular, this paper shows new evidence of the expanding socioeconomic gaps in college access in the presence of higher education selectivity stratification. Students from high SES families have substantial advantages in the access to elite higher education. These students are more likely to gain additional access to selective colleges by responding to the expansion policy in academic preparation and college choice behaviors.

Second, we present the first direct evidence of the differential changes in enrollment, inputs, and student outcomes by institutional stratification. Nearly all the previous research on higher education expansion uses national aggregate data or focuses exclusively on the quantity of higher education opportunities. We show how the highly selectivity-based stratified higher education system in China changed over time during the expansion policy with a focus on the differences between selectivity types. Carnoy et al. (2013) note that all the four BRICs countries become increasingly differentiated with an emphasis on strengthening a limited number of elite institutions. We show that the rapid, controlled expansion even differentiated less-selective institutions. Though all types of colleges have experienced similar trends in the reduced per-student inputs (such as student-faculty ratio and expenditures), there is large, persistent differentiation and stratification between college selectivity levels (Kyvik, 2008).

Third, we examine how returns to different selectivity levels of colleges (or college valueadded) changed during the expansion. Previous studies present mixed findings. Using the 1940-1990 Census data, Juhn et al. (2005) find that the college wage premium reduced during the U.S. higher education expansion. In the United Kingdom, Walker and Zhu (2008) find no significant fall for men and even a large, but insignificant, rise for women in college premium during higher education expansion. Li et al. (2014) document that college expansion in China sharply increased the unemployment rate among college graduates. Our results indicate persistent or even expanding college selectivity premiums in earnings but declining college selectivity premiums in employment when colleges dramatically expanded their enrollments. 
Lastly and most importantly, given that evidence on the impacts of increased enrollment or cohort size on college and labor market outcomes is limited (Stapleton \& Young, 1988; Barr \& Turner, 2013; Kyui, 2016; Bianchi, 2019), we provide new evidence on the causal effect of enrollment expansion on college quality. The expansion policy in China was unexpectedly initiated by the Central Government. Undergraduate enrollment was suddenly expanded by more than $47 \%$ in the first year. Using a difference-in-differences framework based on this natural policy experiment, we compare the variations in college quality by college-cohort that faced different degrees of policy-induced enrollment expansion. On average, enrollment expansion negatively impacted college quality as measured by value-added on graduates' employment and earnings. Each $100 \%$ increase in undergraduate enrollment from 1999 decreases college value-added on wages by about 0.15 standard deviations. These findings are consistent with the evidence from the USA (Stapleton \& Young, 1988), Russia (Kyui, 2016), and Italy (Bianchi, 2019). Moreover, we show that this negative shock would be fully compensated by a comparable increase in investments (especially in faculty resources), which is consistent with the resource overcrowding theory (Bound \& Turner, 2007; Bianchi, 2019).

\section{Background: Chinese higher education expansion in 1999-2012}

There have been three large-scale expansions of college enrollment in the history of Chinese higher education, but the 1958 and 1978 expansions were trivial compared with the 1999-2012 expansion, which is rare in both scale and speed throughout the world. In only thirteen years, undergraduate freshman enrollment increased from 1,083,600 in 1998 to $6,888,300$ in 2012 . The national gross enrollment ratio more than tripled from $9.76 \%$ to $30 \%$. The number of higher education institutions increased from 1,002 to 2,442 .

The 1999 higher education expansion started as an exogenous, unexpected national policy. The worldwide higher education has been often driven by factors such as state policies, economic development, and global competition (Marginson , 2016a). It has been well documented that the China Government initiated this radical expansion policy to stimulate domestic consumption and decrease the labor supply of high school graduates as a response to the Asian Financial Crisis in 1997 (Wan, 2006; Wang, 2014). On January 13, 1999, the State Council ratified The Plan to Revitalize Education in the 21 st Century and set a target of $15 \%$ higher education enrollment ratio by 2010 . This was the earliest policy issued by the Central Government to set an explicit target index for the mass stage of higher education. On June 16, 1999, three weeks before the National College Entrance Exam, the State Development Planning Commission and the Ministry of Education jointly announced the decision to enroll 337,000 more freshmen, in addition to the previously announced 230,000 increased admissions quotas in January, into higher education institutions. Since the College Entrance Exam of 1999 was held during July 7-8, 1999, this unexpected expansion of college enrollment was decided and announced only three weeks before the exam and students already submitted their college applications.

Eventually, college enrollment increased by 513,200 in 1999, a $47.4 \%$ increase from 1998. Ever since that, undergraduate enrollment increased by more than 400,000 each year, reaching 6.85 million freshmen in 2012 from 1.08 million in 1998. Slots for new entrants had risen by six times over a decade. After thirteen year's massive increase in college enrollment, the expansion policy ended unexpectedly. On March 16, 2012, the 
China Ministry of Education announced that "the scale of higher education enrollment needs to be held constant and the enrollment of public four-year institutions will remain unchanged."

Similar to the higher education expansion experiences in many other countries, the enrollment expansion during only thirteen years has largely reshaped the Chinese higher education system in three primary ways. First, access to higher education has been mechanically expanded at a massive scale. In a few years before 1999, about $35 \%$ of high school graduates could enter college. The proportion of college enrollment among high school graduates dramatically reached $56 \%$ in 1999 . The admission rate continued climbing as the number of high school graduates remained stable in the first few years after 1999. The admission rate reached $75 \%$ in 2012 even though families started to respond to the college expansion that more students applied to college. According to Trow (1972) and Trow (1976), a gross enrollment rate between $15 \%-50 \%$ indicates a mass stage of higher education. Chinese government announced in 2010 that the Chinese higher education entered the mass stage with the gross enrollment rate of higher education rising from less than $5 \%$ in 1990 to $25 \%$ in 2010 . The Central Government also targeted that the rate would reach $40 \%$ by 2020 .

Second, the organizational structures of the higher education system also transformed. The enrollment expansion was through two channels. On the intensive margin, each existing college largely increased its admissions quotas from about 4,000 per college in 1998 to over 10,000 per college in 2012 . On the extensive margin, while there were 1,022 colleges in 1998, more than 1,500 new colleges were founded in the next decade. The higher education system in China has stratified into five selectivity tiers of institutions. Among the 2,688 higher education institutions in 2019, at the top are 112 elite public universities of the 211 Program (including the most selective 39 universities of the 985 Program) that receive intensive public funding and policy supports. Next to the elite colleges are non-elite four-year colleges founded before 1999. The fourth tier colleges are newly established public or private four-year colleges in or after 1999. At the bottom of the pyramid are three-year vocational colleges (similar to the U.S. community colleges). The centralized College Entrance Exam system assigns admissions based on students' one-time test scores and applications. The tier-specific admissions cutoffs further differentiate students into different tiers of colleges that students could only apply to colleges within a tier if they have test scores higher than that tier's cutoff.

Third, the dramatic expansion in enrollment without sufficient complementary inputs in teaching resources and finance has negatively affected college quality. Faculty-student ratio, a key indicator of higher education quality indicating class size and faculty availability (Black \& Smith, 2006; Long, 2010), immediately decreased due to the shortage of the supply of high-quality professors in the short and medium terms. In 2007, the Ministry of Education openly admitted that the decision to expand college enrollment in 1999 was too hasty as investments in finance, faculty, and facility did not keep in pace. Furthermore, college tuition largely increased in response to the exceeding needs of financial revenues; however, financial aid was only accessible to a small number of students and at a low level throughout the decade. ${ }^{1}$

\footnotetext{
${ }^{1}$ Yang (2010) finds that, in a sample of 29,806 college students in Beijing in 2008, about $8 \%$ received any government grant and $10 \%$ received any government loan. The mean total government aid amount was $1,082 \mathrm{RMB}$, compared with the mean annual tuition 6,021 .
} 


\section{Theoretical framework}

The expanded enrollment increased access to higher education. However, not all students would benefit from this policy reform. The maximally maintained inequality (MMI) theory and the effectively maintained inequality (EMI) theory have been widely applied to examine the impacts of higher education expansion on the inequality in college access (Raftery \& Hout, 1993; Lucas, 2001). The MMI theory suggests that class barriers will persist until privileged families have attained the desired level of education (a saturation point). Moreover, the EMI theory argues that, even a saturation point is reached, the social background-related inequality will persist as privileged groups use their status advantages to secure quantitatively similar but qualitatively superior educations. Alon (2009) extends the two theories into three prototypes of class inequality - effectively maintained, declining, and expanding - according to the degrees in admissions competition and the adaptation of the privileged to exclusion barriers. In a highly stratified higher education system where competition for access to college (particularly elite college) is high, and high-SES families heavily invest in preparing their children to meet the exclusion criteria, the class divide in higher education is then effectively expanding inequality.

The China case fits the effectively maintained/expanding inequality theory. First, higher education was not universal before and even after the expansion. The college attendance rate was low prior to the expansion. For example, the gross enrollment rate was $9.79 \%$ in 1998. Given the highly stratified higher education system, the level of competition in admissions remained high after the expansion. Second, the centralized college admissions system in China relies solely on the College Entrance Exam, which "restrict(s) access to selective institutions and magnify qualitative differences" (Alon, 2009, p.735). As students from lowSES backgrounds on average have lower scores, they are at a disadvantage even when selective colleges increased slots. Third, the increase in college tuition and fees during expansion enlarged the class divide due to the gaps in the ability to pay for college. In addition, the cumulative effect of many inequalities before college (Wu, 2019) would also add to the socioeconomic gaps, such as informational and behavioral barriers (see summaries in Page \& Scott-Clayton, 2016), proximity to college opportunities (Hillman, 2016), and heterogeneous college-major choice preferences due to limited information or socioeconomic background (Teranishi et al., 2004; Wells \& Lynch, 2012; Hoxby et al., 2013).

Incorporating these macro-level factors into the college choice model that students make choices to maximize their expected returns to college (Manski et al., 1983; Perna, 2006; DesJardins and Toutkoushian, 2005), we hypothesize [1-3] the following: (1) students from high-SES families are at an advantage in access to higher education in all years during the expansion; (2) the advantage increases with college quality tiers; and (3) the advantage increases over time as high-SES families respond to the policy change by increasing testpreparation investment in K-12 education.

The next research question of interest is to examine how enrollment expansion affects higher education production. An extensive literature has examined college quality and its impacts on student outcomes (e.g., Brewer et al., 1999; Dale \& Krueger, 2002, Zhang, 2005b; Black \& Smith, 2006; Dale \& Krueger, 2014; Chetty et al., 2017). All these studies build on the standard education production function: An individual's outcome (e.g., earnings) is a function of the college quality and her own pre-college characteristics. College quality measures the differences in college-level value-added or production to students' outcomes, which is attributable to various college inputs, including measurable resources, faculty, peers, and other unmeasured inputs. We hypothesize [4] that the 
enrollment expansion decreased college production by changing the quality of inputs. Because the expansion was completed in a very short period and without massive complementary supply, the dramatic increase in enrollment largely reduced per-student resources (as "cohort crowding" in Bound \& Turner, 2007). In particular, since the supply of highquality faculty members was fixed in the short term, faculty-student ratio - a key college input - declined during the expansion that might have resulted in the popularly criticized "college credential inflation" in recent years (Levin \& Xu, 2005). The other important change in inputs was peer quality. Given the fixed supply of college applicants in the short term, increasing enrollment would mechanically decrease the average peer quality (similar to the US experience, Taubman et al., 1972), which might also negatively impact college quality.

However, it is an empirically open question how college quality changed during the expansion as China started to invest heavily in higher education at the same time, particularly to elite universities (Carnoy et al., 2013; Wang, 2014; Yang \& Wang, 2020). Given the inequality in investment and the high selection in the College Entrance Exam, we hypothesize [5] that the stratification in higher education institutions would persist and even enlarge; but the negative shock in college quality by increased enrollment in those non-selective colleges might not be sufficiently compensated by investment.

Regarding the policy impact heterogeneity, the rising selectivity in the elite colleges would serve as "the great equalizer" (Hout, 2012; Zhou, 2019). We hypothesize [6] that students benefit equally from attending a small number of elite colleges (Hoxby, 2009). Moreover, "hard science majors" with higher average costs were more difficult to expand (Hemelt et al., 2020) and in practice less likely to expand enrollment, we hypothesize [7] that engineering-focused colleges had higher college quality premiums during the expansion.

\section{Data and descriptive evidence}

\section{College-level data}

We use college-level data from the newly available China Educational Finance StatisticsPostsecondary data (CEFS-Postsecondary) from the Ministry of Education and the Ministry of Finance in China. The CEFS-Postsecondary data, similar to the U.S. Integrated Postsecondary Education Data System (IPEDS), contain yearly information of every higher education institution in China except for military and Sino-foreign joint institutions. We primarily use the following three types of data. Enrollment data include end-of-year and beginning-of-year unduplicated headcount of students, separately for undergraduate and graduate students. Human resources data measure the number of employees by faculty status and retirement status. Finance data include revenues by source and expenses by function. As one of the few researchers with access to the confidential NEFS data, by data agreement, we only have access to data in 1998 and the years that match the enrollment years in the student survey.

The focus of this paper is the stratification of higher education institutions: top, elite, four-year (existing prior to 1999), four-year (new), and vocational colleges. We use additional information from the Ministry of Education to identify the types of colleges. First, we obtain the identifiers of the top (39 universities in the 985 Program) and elite (73 universities in the 211 Program but not in the 985 Program) colleges, as well as four-year 
colleges and three-year vocational colleges from the institutional characteristics catalog. Next, we append the yearly report list of newly built colleges or renamed colleges from 1998 to 2012 to identify four-year colleges that were built before or after the expansion.

We use three primary college inputs: total expenditure, operating expenditure, and personnel expenditure (i.e., faculty salary). All of these variables are measured as per student each year. We use per-student faculty salary information to control for both the quantity and quality of faculty inputs. Results are similar but nosier when using faculty-student ratio as the input measure. As will be discussed below, the small number of college-year observations in the survey data limit the analysis on a wide array of college-level characteristics. However, existing literature shows that these three input measures are among the key college quality proxies (Dale \& Krueger, 2002; Black \& Smith, 2004).

\section{Student-level data}

Student-level data are from the National Survey on College Graduates' Employment (NSCGE) by the Institute of Economics of Education at Peking University. The NSCGE surveyed a nationally representative sample of college graduates in June of 2003, 2005, 2007, 2009, 2011, and 2013, which covered all tiers of higher education institutions in China. See details about the stratified probability sampling at the college-major level in 2003-2009 in Yue (2015). The later two rounds followed the same survey designs. Similar to other college student surveys (e.g., the China College Student Survey in Luo et al. (2018), the Beijing College Students Panel Survey in Wu (2019)), the NSCGE used a twostage stratified sampling process. First, colleges were randomly selected within strata by geographic area, type, and institutional tiers. There were 45 colleges in the 2003 survey and about 30 colleges in the subsequent surveys. The college characteristics within strata are comparable across years. Second, 500-1000 senior students were randomly selected from each sampling college. Table 1 reports the number of respondents by survey year, which varies due to different colleges sampled in different years. The 18,467 respondents in 2003 represent about $1 \%$ of the two million graduates. Since only about $4 \%$ of students attended elite institutions, these institutions were purposely over-sampled (lower-ranked colleges were under-sampled): $15 \%$ top college students, $10 \%$ elite, $30 \%$ four-year (existing), $20 \%$ four-year (new), and $15 \%$ three-year.

The NSCGE data include detailed student-level information on demographics, family background (parental education and occupations), pre-college and college experience, and early labor market outcomes upon graduation. Importantly, the survey questionnaire design and data structure of the six surveys are comparable. The code system of various categorical measures remained consistent in the 14 years, such as the definition of employment, parental occupations, and family residence levels (metropolis, medium city, rural county, rural). We match the survey sample to the institutional data by college and year. The final cross-sectional sample of six cohorts includes 113,435 student-level observations (393 observations from the original sample were dropped due to non-match) in 259 college-year cells (176 unique college observations).

The NSCGE data are the only available multi-period, nationally representative random sample survey data. The survey spanned a long time period during the higher education expansion in China, starting from the first cohort that experienced enrollment expansion. With detailed information on students' college attendance and postgraduation outcomes, we are able to estimate the policy impacts on both access and production. However, we 
Table 1 Summary statistics

\begin{tabular}{|c|c|c|c|c|c|c|}
\hline & \multicolumn{6}{|c|}{ College freshman cohort } \\
\hline & 1999 & 2001 & 2003 & 2005 & 2007 & 2009 \\
\hline High SES & $19.31 \%$ & $21.16 \%$ & $19.51 \%$ & $19.32 \%$ & $17.51 \%$ & $20.19 \%$ \\
\hline On first generation & $25.44 \%$ & $30.29 \%$ & $30.58 \%$ & $29.63 \%$ & $28.03 \%$ & $30.43 \%$ \\
\hline Upper & $35.02 \%$ & $32.89 \%$ & $30.23 \%$ & $29.60 \%$ & $27.63 \%$ & $28.29 \%$ \\
\hline Female & $40.79 \%$ & $42.46 \%$ & $44.79 \%$ & $46.04 \%$ & $50.71 \%$ & $47.16 \%$ \\
\hline Minority & $10.34 \%$ & $11.11 \%$ & $5.75 \%$ & $5.86 \%$ & $6.02 \%$ & $8.35 \%$ \\
\hline Age at survey & 21.54 & 22.23 & 21.65 & 22.40 & 22.06 & 22.71 \\
\hline Initial monthly wage & 2097.51 & 2090.75 & 2121.63 & 2522.44 & 2520.69 & 3206.87 \\
\hline Initial employment* & $32 \%$ & $49 \%$ & $54 \%$ & $41 \%$ & $52 \%$ & $53 \%$ \\
\hline Initial employment** & $53 \%$ & $65 \%$ & $59 \%$ & $59 \%$ & $62 \%$ & $60 \%$ \\
\hline Initial employment*** & $63 \%$ & $73 \%$ & $73 \%$ & $69 \%$ & $74 \%$ & $73 \%$ \\
\hline $\mathrm{N}$ & 18,467 & 21,205 & 16,382 & 21,771 & 19,766 & 15,844 \\
\hline
\end{tabular}

This table presents the summary statistics of the key covariates and outcomes from the survey data, separately by college freshman cohorts. To simplify the notations of comparisons, students from three-year vocational colleges are coded four years back from their graduation years, in the same way as students in four-year colleges. Initial wage is CPI-adjusted to have a constant price in year 2013. * Employment is defined as having nonzero wages; ** Employment is defined as students reported to be employed or to continue graduate studies; *** Employment is defined as students reported to be employed, job offer pending, self-employed, or to continue graduate studies

cannot identify the sharp changes before and after the expansion policy started in 1999 as we do not have data on students who enrolled in college before 1999; instead, we examine the changes in access and production during the expansion.

We measure the quality-differential access to higher education by examining the socioeconomic gap in the probability of attending colleges at the five stratified selectivity tiers. Using information from detailed parental education (7 categories) and occupations (11 categories), we define a student is from an "upper SES" household if she is (1) not a firstgeneration college student (i.e., parents do not have a college degree) and (2) with parents having upper-level jobs including managers and government officials.

The production outcome of interest is initial wage, measured as the monthly self-reported wage in a student's first job upon graduation. Wage is the most widely used measure of college student labor market outcomes (e.g., Zhang, 2005b; Gaertner et al., 2014; Chetty et al., 2017). There are two concerns regarding the wage data. First, the wage information might be censored as students with extremely high or low wages were usually less likely to report their true wages. We censored the data in the range of 500-20,000. Results are robust when we vary the top and bottom limits. We also perform robustness checks using the Tobit model. Results are qualitatively unchanged compared with the OLS estimates.

Second, though most of the students who had received job offers $(99.5 \%)$ reported their initial wages, those who had pending decisions or in self-employment at the time of survey did not report this information. Moreover, many students choose to continue graduate studies and college quality matters in their decisions (Zhang, 2005a; Posselt \& Grodsky, 2017). To supplement the wage analysis, we construct several "employment" indicators that include or exclude those students and found similar results: (1) a dichotomous variable indicating nonzero wage, (2) a dichotomous variable indicating having received a job offer 
or graduate school admissions, and (3) a dichotomous variable indicating non-unemployment that includes all types of employment and graduate studies. We do not separately analyze graduate studies. This outcome measure is imprecise as we do not have information of which graduate school a student was going to attend. Graduate schools are also highly stratified in China as in many other countries (Posselt \& Grodsky, 2017). Simply looking at whether a student attended graduate school will mask the quality differentiation. ${ }^{2}$

\section{Descriptions of the higher education expansion}

Previous research has already shown the sharp increase in the total college enrollment from 1999 using aggregate data from the China National Bureau of Statistics (Yeung, 2013; Li et al., 2014; Ou \& Hou, 2019). We present the first evidence on the differential changes in enrollment, inputs, and student access outcomes by institutional stratification.

Figure 1 shows the enrollment expansion from 1997 to 2013 using the CEFS-Postsecondary data. Overall, there was little change prior to the expansion policy in 1999. Panel (a) shows the extensive margin of expansion that the numbers of both four-year and three-year vocational colleges increased dramatically after 2001, which took about two years to build new colleges since the expansion policy started. The number of three-year vocational colleges experienced a much larger increase than that of four-year colleges. Panel (b) shows the difference in the intensive margin between four-year and three-year colleges. The average college size as measured by the number of undergraduate students increased immediately after 1999. While four-year colleges expanded enrollment more than three-vocational colleges at the absolute level, both types of colleges nearly tripled their numbers of undergraduate students.

Combining the increases at the extensive and intensive margins, Panel (c) plots the total number of undergraduate students by the stratified institutional selectivity. The small number of top and elite colleges were relatively stable in their shares of undergraduate students, while the other three lower-tier colleges greatly increased their total numbers of undergraduate students. On average, as Panel (d) suggests, there was clearly stratification in college size that higher-tier colleges had more undergraduate students and all types of colleges increased their enrollment sizes during the enrollment expansion policy.

Meanwhile, there were also large changes in higher education inputs. As discussed earlier, student-faculty ratio, a proxy of college instructional quality, immediately increased due to the fixed faculty supply in the short term. Panel (a) of Fig. 2 shows the changes in student-faculty ratio by institutional stratification. All colleges experienced immediate, large increases in the number of students per faculty after 1999. Lower-tier colleges had a much higher student-faculty ratio that also increased at a higher rate, partly due to their limited financial resources as suggested by the differences in per-student expenditures by institutional tiers in Panel (b). The top and elite colleges had largely increased their spending levels, which may have compensated the negative shocks of enrollment expansion on college

\footnotetext{
2 There is a quantity-quality tradeoff. Taking graduate studies in China as an example, top colleges have smaller numbers of students who continue graduate studies domestically. In contrast, some lower-ranked colleges have large number of students going to graduate school. In this case, using "whether a student continues graduate studies in China" will overstate the production effects of some lower-ranked schools and understate that of some higher-ranked schools.
} 


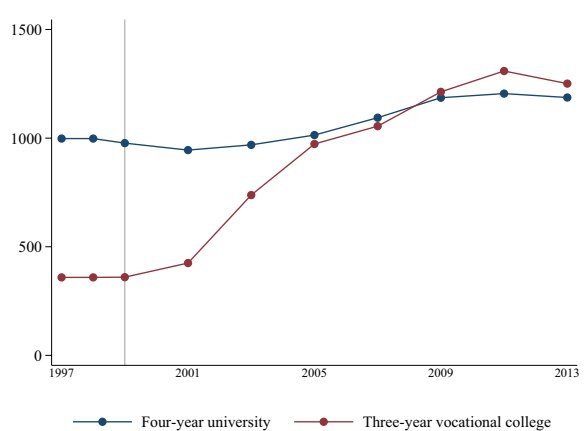

(a) Number of colleges in the sample

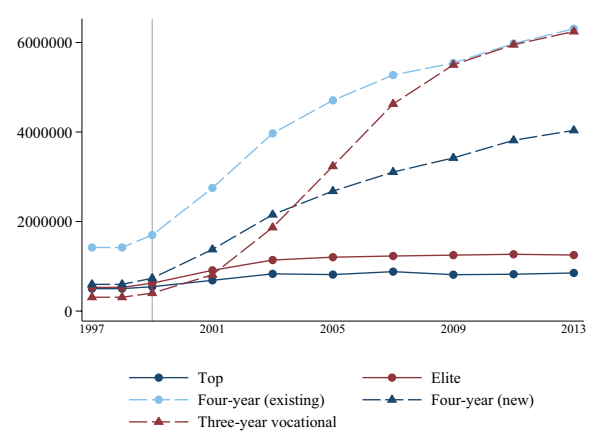

(c) Number of undergraduate students in total

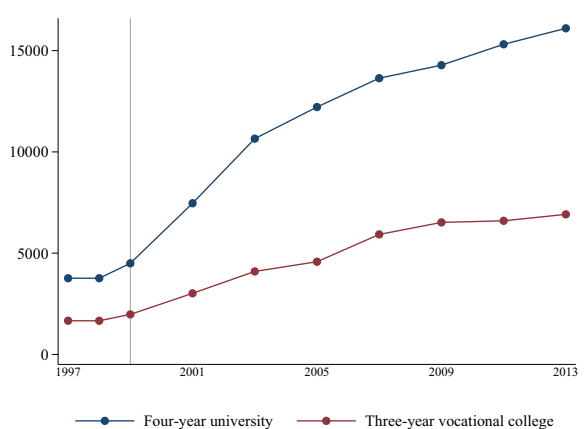

(b) Number of undergraduate students per college

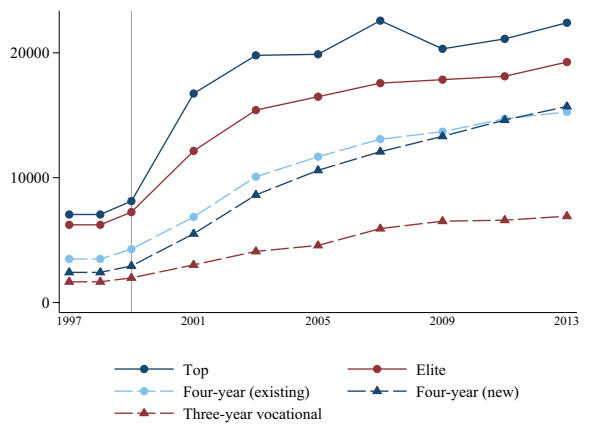

(d) Number of undergraduate students per college

Fig. 1 College enrollment expansion at the national scale. Notes: This figure describes the college enrollment expansion at the national scale, and by institutional selectivity in China using the China Educational Finance Statistics - Postsecondary data (CEFS-Postsecondary) compiled by the China Ministry of Education and the China Ministry of Finance. Panel (a) plots the number of four-year universities and Threeyear Vocational colleges from 1997 to 2013, the extensive margin of expansion. Panel (b) plots the number of undergraduate students per college, the intensive margin of expansion. Panel (c) plots the number of undergraduate students in total. Panel (d) plots the number of undergraduate students per college. Top includes the 39 universities in the "985 Program." Elite includes the 73 universities in the "211 Program" but not in the "985 Program." Four-year (existing) includes four-year universities that were founded before 1999. Four-year (new) includes four-year universities that were founded in or after 1999, some of which were three-year vocational colleges before 1999. Three-year vocational includes all the three-year vocational colleges. The vertical gray line indicates the year 1999 when the expansion started

quality. Given the limited resources, lower-tier colleges that experience rapid increases in enrollment, were more likely to experience a large decline in their college quality.

Table 1 presents the summary statistics of student demographics and labor market outcomes by enrollment cohorts in the student survey data. Though sampling weight is not available for analysis, the unweighted statistics show important information of changes in Chinese higher education given the representativeness of the sample. The first panel presents the mean proportion of students from high-SES families in all types of colleges, which were quite stable during the expansion. Panels (a) and (b) of Fig. 3 show the highly stratified access to different institution selectivity tiers and the average proportion of highSES students in selective institutions increased in the early years after the enrollment expansion started, which supports the effectively expanding inequality theory. The second panel of Table 1 suggests that there is no gender difference in the access to college, but 
Fig. 2 Changes in higher education inputs during the expansion. Notes: This figure describes the changes in higher education inputs (student-faculty ratio in Panel a); total expenditure per student in Panel b) during the expansion by institutional selectivity using the national data

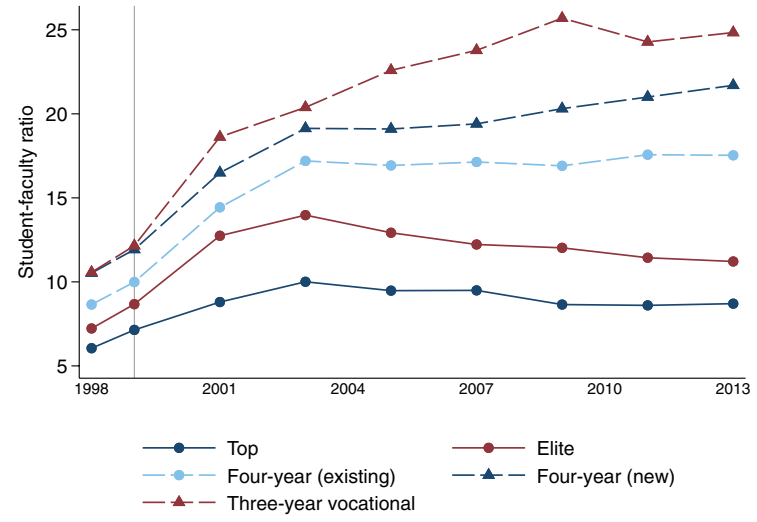

(a) Student-faculty ratio

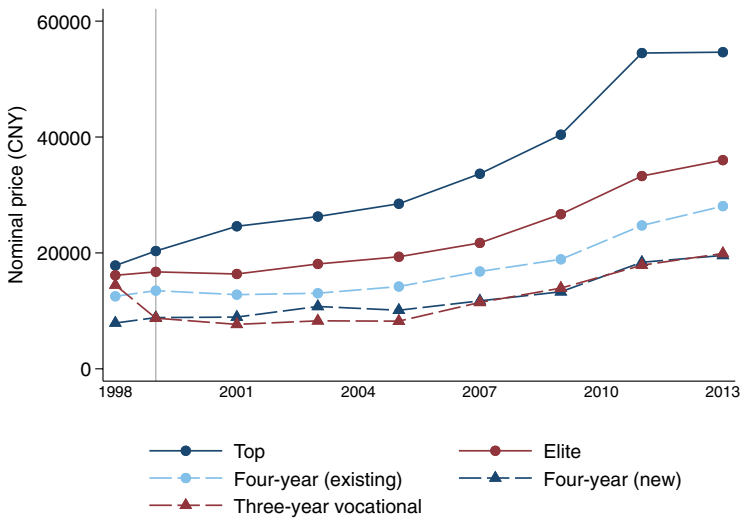

(b) College expenditure per student

fewer ethnic minority students gained access to college in later years. The decline of students with low-SES or ethnic minority backgrounds motivated China to implement a set of affirmative action admissions policies (Zhou \& Hill, 2009).

The last panel of Table 1 reports the mean labor market outcomes by cohorts. The average starting monthly wage slightly increased from about $\$ 300$ in 2003 to $\$ 350$ in 2011, and a large jump to $\$ 450$ in 2013 . This rise of wage should not be interpreted as causal results of the enrollment expansion but is mainly driven by the economic growth changes in China (Li et al., 2017), which will be controlled for by year fixed effects in the estimation models. About half of the college graduates reported to have nonzero wages. Exceptions are in year 2003 (for the 1999 cohort) when the SARS delayed students job search and in year 2009 (for the 2005 cohort) when the Financial Crisis of 2008 negatively shocked the labor market. About another $20 \%$ of students continued graduate studies and $10 \%$ of students had pending job offers by the time of graduation or chose to be self-employed. These unweighted average employment outcomes are consistent with national statistics provided by the Chinese Ministry of Education. 


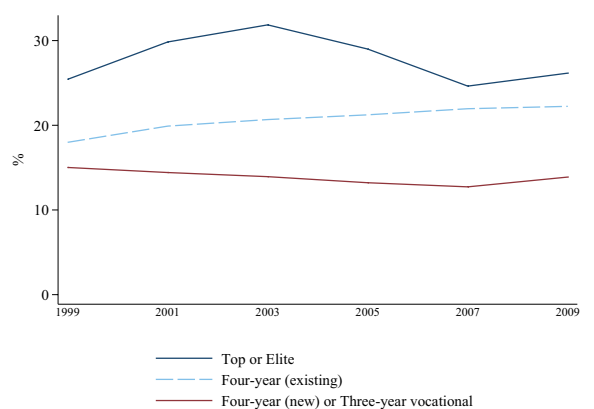

(a) Three groups

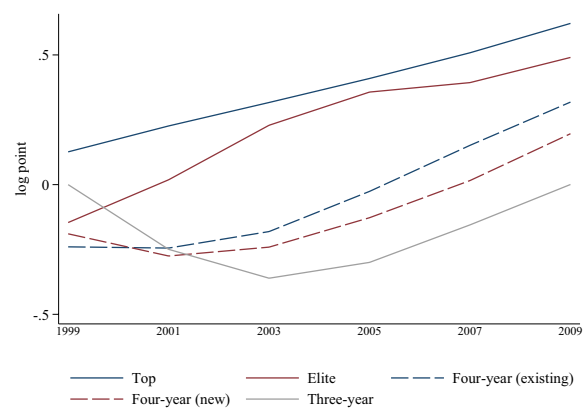

(c) Initial wages

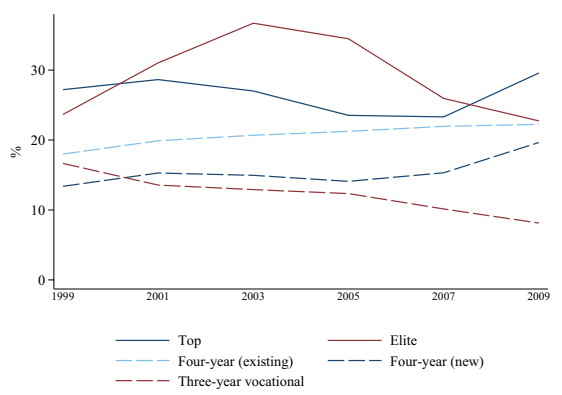

(b) Five groups

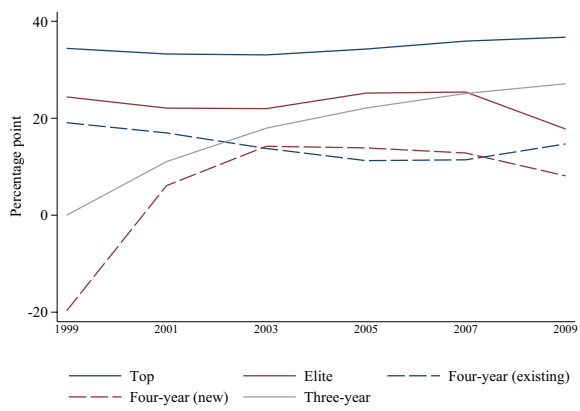

(d) Initial employment

Fig. 3 Stratified access and production in higher education by institutional selectivity. Notes: The top two panels show the share of college enrollment from upper SES family background by institutional selectivity using data from the National College Student Graduation Survey, 2003-2013. Panel (a) presents the threegroup comparisons and Panel (b) presents the five-group comparisons. The bottom two panels plot the estimated college value-added across years by institutional selectivity, separately for outcomes of initial wages in Panel (c) and initial employment in Panel (d). To foresee the yearly trends, each line is plotted using the locally weighted smoothing approach

\section{Unequal access to (elite) higher education}

We use a multinomial logistic regression to model the types of colleges that a student enrolled at, including top, elite, four-year (existing), four-year (new), and three-year vocational colleges. The probability of a student enrolling at college type $i$ (vs. three-year vocational colleges as the reference group, $Y=1) \mathbf{P}(Y=i)$ is:

$$
\mathbf{P}(Y=i)=\frac{\exp \left(\alpha_{i} \text { Upper } S E S+X \beta_{i}\right)}{\sum_{k=1}^{J} \exp \left(\alpha_{k} \text { Upper } S E S+X \beta_{k}\right)},
$$

where $X$ is a vector of covariates, including gender, race, age, family residence, and enrollment year fixed effects. The parameter of interest $\alpha_{i}$ estimates the difference between students in upper SES families and those in lower SES families in the log of relative risk ratios of enrolling at college type $i$ compared with enrolling at the reference group - threeyear vocational colleges.

In addition to estimating the overall SES gap during the entire college expansion period, we also estimate the heterogeneous trends overtime between upper SES students and their 
Table 2 Stratified access to higher education during expansion
(1)
(2)
(3)
(4)

MNL reference group: vocational college

\begin{tabular}{lll}
\hline Top & Elite & $\begin{array}{l}\text { Four-year } \\
\text { (existing) }\end{array}$
\end{tabular}

\section{A. Baseline model}

$\begin{array}{lllll}\text { Upper SES } & 1.154 * * * & 1.038 * * * & 0.845 * * * & 0.433 * * * \\ & (0.098) & (0.115) & (0.090) & (0.104)\end{array}$

\section{B. Heterogeneous yearly trends} vs. 1999

\begin{tabular}{|c|c|c|c|c|}
\hline Upper*2001 & $\begin{array}{l}0.474 \\
(0.364)\end{array}$ & $\begin{array}{l}0.384 \\
(0.440)\end{array}$ & $\begin{array}{l}0.565 \\
(0.401)\end{array}$ & $\begin{array}{l}0.579 \\
(0.604)\end{array}$ \\
\hline Upper*2003 & $\begin{array}{l}0.137 \\
(0.339)\end{array}$ & $\begin{array}{l}1.139 \\
(1.061)\end{array}$ & $\begin{array}{l}0.106 \\
(0.349)\end{array}$ & $\begin{array}{l}0.299 \\
(0.421)\end{array}$ \\
\hline Upper*2005 & $\begin{array}{l}-0.255 \\
(0.348)\end{array}$ & $\begin{array}{l}0.508 \\
(0.416)\end{array}$ & $\begin{array}{l}0.316 \\
(0.353)\end{array}$ & $\begin{array}{l}-0.024 \\
(0.461)\end{array}$ \\
\hline Upper*2007 & $\begin{array}{l}0.090 \\
(0.284)\end{array}$ & $\begin{array}{l}0.527 \\
(0.399)\end{array}$ & $\begin{array}{l}0.715^{* *} \\
(0.298)\end{array}$ & $\begin{array}{l}0.632 \\
(0.440)\end{array}$ \\
\hline Upper*2009 & $\begin{array}{l}0.807 * * * \\
(0.311)\end{array}$ & $\begin{array}{l}0.681 \\
(0.437)\end{array}$ & $\begin{array}{l}0.976^{* * * *} \\
(0.367)\end{array}$ & $\begin{array}{l}1.207 * * * \\
(0.414)\end{array}$ \\
\hline C. Linear year trends & & & & \\
\hline Upper SES & $\begin{array}{l}0.853 * * * \\
(0.184)\end{array}$ & $\begin{array}{l}0.595^{* * * *} \\
(0.222)\end{array}$ & $\begin{array}{l}0.355^{*} \\
(0.196)\end{array}$ & $\begin{array}{l}-0.115 \\
(0.250)\end{array}$ \\
\hline Upper*Linear trend & $\begin{array}{l}0.047 \\
(0.029)\end{array}$ & $\begin{array}{l}0.077 * * \\
(0.036)\end{array}$ & $\begin{array}{l}0.087 * * * \\
(0.029)\end{array}$ & $\begin{array}{l}0.096 * * * \\
(0.037)\end{array}$ \\
\hline $\begin{array}{l}\text { D. Decomposing the "upper } \\
\text { SES" status }\end{array}$ & & & & \\
\hline High parental jobs & $\begin{array}{l}0.151 \\
(0.175)\end{array}$ & $\begin{array}{l}-0.025 \\
(0.193)\end{array}$ & $\begin{array}{l}-0.162 \\
(0.172)\end{array}$ & $\begin{array}{l}-0.163 \\
(0.202)\end{array}$ \\
\hline High parental jobs*Linear trend & $\begin{array}{l}0.053 * \\
(0.030)\end{array}$ & $\begin{array}{l}0.079 * * \\
(0.034)\end{array}$ & $\begin{array}{l}0.079 * * * \\
(0.029)\end{array}$ & $\begin{array}{l}0.046 \\
(0.033)\end{array}$ \\
\hline Non-first generation & $\begin{array}{l}0.768 * * * \\
(0.152)\end{array}$ & $\begin{array}{l}0.638 * * * \\
(0.168)\end{array}$ & $\begin{array}{l}0.470 * * * \\
(0.161)\end{array}$ & $\begin{array}{l}-0.069 \\
(0.198)\end{array}$ \\
\hline Non-FG*Linear trend & $\begin{array}{l}0.005 \\
(0.026)\end{array}$ & $\begin{array}{l}0.011 \\
(0.027)\end{array}$ & $\begin{array}{l}0.029 \\
(0.026)\end{array}$ & $\begin{array}{l}0.083 * * \\
(0.034)\end{array}$ \\
\hline
\end{tabular}

This table presents results from multinomial logistic regressions. Coefficients of multinomial log-odds are reported. Standard errors in parentheses are clustered at the college-year level. The multi-valued outcome includes five groups of colleges: top, elite, four-year (existing), four-year (new), and three-year vocational (reference group). Each panel is from a separate regression. All the regressions control for student demographics (gender, race, age, family residence), year fixed effects, and dummy indicators for missing items. Upper SES is defined as a student is (1) not a first-generation college student and (2) from a household with upper-level parental jobs. Linear year trend codes year 1999 as zero. ${ }^{*}$ significant at 10\%; ${ }^{*} *$ significant at $5 \%$; *** significant at $1 \%$ 
counterparts. Theoretically, the highly hierarchical categories of institutional selectivity from least to most selective can be modeled using an ordered logit model that will be more efficient than a multinomial logit model. However, similar to many US studies that use multinomial instead of ordered logit regression, violating the parallel slopes assumption makes the ordinal model is not appropriate (Perna \& Titus, 2004; Rodriguez et al., 2018).

Table 2 presents the multinomial logit model results. The results provide clear evidence of the unequal access to elite higher education during the enrollment expansion. Each panel reports estimates from a separate model, and each column reports estimates for one college category $i$ within a regression. Panel A estimates the basic model in Eq. 1. Relative to students from lower SES backgrounds, upper SES students had a statistically significantly higher probability of enrolling at a more-selective college compared with enrolling at a three-year vocational college. This SES gap is much larger in selective college opportunities. For instance, compared with lower SES students, upper SES students had a $217 \%$ $(=\exp (1.154)-1)$ higher probability of enrolling at the top colleges compared with enrolling at a three-year vocational college. The difference between three-year vocational colleges and four-year colleges newly built after 1999 was smaller, but still economically and statistically significant.

In Panel B, we add the interaction terms between the upper SES indicator and enrollment cohort indicators to examine the heterogeneous time trends. Coefficients on "upper SES" show that the SES gap existed in the first year of expansion. Nearly all of the coefficients on the interaction terms are positive, which suggests that the SES gap was likely to increase over time during the entire expansion period. The gap largely widened for the 2009 freshman cohort. One potential reason is that most of Chinese provinces changed their college admissions mechanisms that students from upper SES families may have better information and strategy to gain the entry into more selective colleges, even holding College Entrance Exam scores equal (Ye, 2018; Ha et al., 2020).

To increase power by reducing the number of parameters, Panel $\mathrm{C}$ fits a linear year trend model. Panels A and B of Fig. 3 show that a linear year trend model is a good approximation of the changes in access to different types of colleges. Results show a similar story that the SES gap expands over years. Finally, we decompose the SES gap into the two dimensions: (1) parents had manager-/government-level jobs, and (2) parents received college degrees. Consistently, advantaged students had a much higher chance of entering elite higher education, which increased with the expansion of the slots for new college entrants.

We should note that we do not have data on students' College Entrance Exam scores. Therefore, as discussed in the theoretical framework, the estimated SES gap in the access to elite higher education consists of differences in both academic achievements and other factors between high- and low-SES students. However, the estimated SES gap, which meaningfully captured the inequality in college opportunities, would not be entirely attributed to the difference in academic achievements. First, due to the sudden, exogenous policy change, students' academic achievements were not able to respond to the enrollment expansion sharply at least in the short term. Second, even having the same test scores, disadvantaged students were still less likely to enter colleges (especially elite colleges) due to college choice preferences and informational barriers (Li et al., 2015; Ye, 2018). 
Table 3 Stratified production of higher education during expansion

\begin{tabular}{|c|c|c|c|c|c|c|c|}
\hline & (1) & (2) & (3) & (4) & (5) & (6) & (7) \\
\hline & \multicolumn{4}{|c|}{$\ln$ (Monthly wage) } & \multicolumn{3}{|c|}{ Employment } \\
\hline & \multicolumn{4}{|l|}{$\mathrm{N}=52,990$} & \multicolumn{3}{|l|}{$\mathrm{N}=113,435$} \\
\hline & & & & & Measure 1 & Measure 2 & Measure 3 \\
\hline \multicolumn{8}{|l|}{ vs. vocational } \\
\hline Top & $\begin{array}{l}0.654 * * * \\
(0.066)\end{array}$ & $\begin{array}{l}0.530 * * * \\
(0.139)\end{array}$ & $\begin{array}{l}0.527 * * * \\
(0.134)\end{array}$ & $\begin{array}{l}0.548 * * * \\
(0.133)\end{array}$ & $\begin{array}{l}-0.039 \\
(0.059)\end{array}$ & $\begin{array}{l}0.356 * * * \\
(0.069)\end{array}$ & $\begin{array}{l}0.260 * * * \\
(0.062)\end{array}$ \\
\hline \#Linear trend & & $\begin{array}{l}0.017 \\
(0.021)\end{array}$ & $\begin{array}{l}0.014 \\
(0.020)\end{array}$ & $\begin{array}{l}0.010 \\
(0.020)\end{array}$ & $\begin{array}{l}-0.025^{* * *} \\
(0.009)\end{array}$ & $\begin{array}{l}-0.016^{*} \\
(0.009)\end{array}$ & $\begin{array}{l}-0.021 * * \\
(0.008)\end{array}$ \\
\hline Elite & $\begin{array}{l}0.450 * * * \\
(0.065)\end{array}$ & $\begin{array}{l}0.213 \\
(0.134)\end{array}$ & $\begin{array}{l}0.214^{*} \\
(0.128)\end{array}$ & $\begin{array}{l}0.225^{*} \\
(0.129)\end{array}$ & $\begin{array}{l}0.032 \\
(0.064)\end{array}$ & $\begin{array}{l}0.234 * * * \\
(0.080)\end{array}$ & $\begin{array}{l}0.179 * * * \\
(0.069)\end{array}$ \\
\hline \#Linear trend & & $\begin{array}{l}0.043 * * \\
(0.018)\end{array}$ & $\begin{array}{l}0.040 * * \\
(0.017)\end{array}$ & $\begin{array}{l}0.038 * * \\
(0.017)\end{array}$ & $\begin{array}{l}-0.035^{* * *} \\
(0.009)\end{array}$ & $\begin{array}{l}-0.018 \\
(0.012)\end{array}$ & $\begin{array}{l}-0.024 * * \\
(0.010)\end{array}$ \\
\hline $\begin{array}{l}\text { Four-year } \\
\text { (existing) }\end{array}$ & $0.231 * * *$ & 0.039 & 0.035 & 0.072 & -0.038 & $0.146^{* *}$ & $0.111^{*}$ \\
\hline & $(0.052)$ & $(0.123)$ & $(0.117)$ & $(0.115)$ & $(0.055)$ & $(0.074)$ & $(0.065)$ \\
\hline \#Linear trend & & $\begin{array}{l}0.032 * * \\
(0.016)\end{array}$ & $\begin{array}{l}0.030 * * \\
(0.015)\end{array}$ & $\begin{array}{l}0.027 * \\
(0.015)\end{array}$ & $\begin{array}{l}-0.039 * * * \\
(0.008)\end{array}$ & $\begin{array}{l}-0.027 * * \\
(0.012)\end{array}$ & $\begin{array}{l}-0.031 * * * \\
(0.010)\end{array}$ \\
\hline Four-year (new) & $\begin{array}{l}0.144 * * * \\
(0.049)\end{array}$ & $\begin{array}{l}0.041 \\
(0.127)\end{array}$ & $\begin{array}{l}0.044 \\
(0.120)\end{array}$ & $\begin{array}{l}0.075 \\
(0.118)\end{array}$ & $\begin{array}{l}-0.148^{* *} \\
(0.057)\end{array}$ & $\begin{array}{l}-0.081 \\
(0.080)\end{array}$ & $\begin{array}{l}-0.098 \\
(0.071)\end{array}$ \\
\hline \#Linear trend & & $\begin{array}{l}0.015 \\
(0.016)\end{array}$ & $\begin{array}{l}0.012 \\
(0.015)\end{array}$ & $\begin{array}{l}0.009 \\
(0.015)\end{array}$ & $\begin{array}{l}-0.016^{*} \\
(0.009)\end{array}$ & $\begin{array}{l}-0.002 \\
(0.011)\end{array}$ & $\begin{array}{l}-0.001 \\
(0.010)\end{array}$ \\
\hline $\begin{array}{l}\text { Flexible con- } \\
\text { trols }\end{array}$ & No & No & Yes & Yes & Yes & Yes & Yes \\
\hline $\begin{array}{l}\text { Major fixed } \\
\text { effects }\end{array}$ & No & No & No & Yes & Yes & Yes & Yes \\
\hline
\end{tabular}

This table presents OLS regression estimates on the group-level college value-added measures in initial wages (conditional on employment) and employment among college graduates in the six cohorts included in the survey data. Monthly wages are censored between 500 to 20,000. Results from using different censoring thresholds or using a Tobit model on the wage regression are similar. Employment is defined to have a non-zero wage job (measure 1). Results are similar when including graduate studies and self-employment as a broad measure of non-unemployed (measure 2 and measure 3). Standard errors inparentheses are clustered at the college-year level. All the regressions control for student demographics (gender, race, age, family residence), year fixed effects, and dummy indicators for missing items. Linear year trend codes year 1999 as zero. Flexible controls include the detailed parental education levels (5 levels) and job categories (11 types) by adding three way interactions of parental education, job, and urbanicity levels (4 levels), separately for mother and father. Major includes thirteen major groups. * significant at $10 \%$; ** significant at $5 \%$; *** significant at $1 \%$

\section{Stratified production during higher education expansion}

\section{Measuring the impacts of college quality on labor market outcomes}

Following the long literature that measures the impacts of college quality on labor market outcomes (Brewer et al., 1999; Black \& Smith, 2004; Zhang, 2005b; Long, 2010; Borgen, 2014; Dale \& Krueger, 2014), we use the following OLS model: 


$$
Y_{i j t}=\beta * X_{i j t}+\gamma_{j t}+\delta_{t}+\varepsilon_{i j t}
$$

where $Y_{i j t}$ is the labor market outcome for student $i$ who graduated from college $j$ in year $t$. Note that the data are cross-sectional that we can only observe each student once. The key parameter of interest $\gamma_{j t}$ measures college $j$ 's impact on the labor market outcomes of students in cohort $t$, holding a set of pre-college covariates $X_{i j t}$ (gender, race, age, family residence) and common time shocks $\delta_{t}$ constant. $\varepsilon_{i j t}$ is a stochastic term representing unmeasured impact factors of labor market outcomes.

Unlike the studies that identify the impacts of institutional quality characteristics, we focus on identifying $\gamma_{j t}$, as similar to a value-added model (Hanushek \& Rivkin, 2010; Cunha \& Miller, 2014; Chetty et al., 2014a). We then study how college quality $\gamma_{j t}$ changed over time during the enrollment expansion. To address the potential omitted variable bias, we include flexible controls of family backgrounds by adding three-way interactions of detailed parental education levels (8 levels), parental job categories (12 levels), and family residence urbanicity levels (4 levels). These flexible controls are sufficient statistics for the inequality in family resources and individual earnings potential (Wu, 2019). Furthermore, since the Chinese centralized college admissions system requires students to submit college-and-major admissions, we also include major categories that students enrolled at to control for preference heterogeneity.

To present the evidence of stratified higher education production, we estimate Eq. 2 by replacing the college-year fixed effects with college group-year fixed effects in $\gamma_{j t}$. In Table 3, we start with a baseline model that does not allow the college group fixed effects to vary across years in column (1). Results show that, on average, higher education institutional selectivity is statistically significantly and positively correlated with an increase in postgraduation earnings. For example, students graduating from the top colleges earned $92 \%(=\exp (0.654)-1)$ more than students graduating from three-year vocational colleges. Similar to the differential access to college, the differences between less selective four-year colleges and three-year colleges are smaller, but still statistically significant. In column (2), we add the linear time trends interactions to examine how the college selectivity/quality premium changed overtime during the expansion policy. We find that the stratified production existed from the first year of higher education expansion, particularly between selective and non-selective colleges. The coefficients of the linear time trends interactions are positive, which suggests that the stratification in production might have expanded, although imprecisely estimated. For instance, the gap in log of monthly wage between elite and three-year vocational colleges was 0.213 for the 1999 freshman cohort, which increased by $0.043(p<0.05)$ each year and nearly doubled for the 2009 cohort. We further control for detailed family background information and major groups in columns (3) and (4) to minimize potential omitted variable bias. Estimates remain unchanged.

Panel (c) of Fig. 3 shows the results using the full model of Eq. 2 with 30 parameters of $\gamma_{j t}(6$ cohorts and 5 college selectivity categories; three-year vocational in 1999 is normalized as the reference point). Consistent with the estimates as discussed above in Table 3, the more selective colleges had higher value-added in boosting students' initial wages upon graduation. Notably, three-year vocational colleges experienced a large decrease in their value-added quality in the first few years of the expansion. These vocational colleges increased students' wages more than most of the four-year colleges at the beginning of the expansion. This might be because that vocational colleges were better at preparing students for the labor market employment. But this advantage quickly disappeared as all colleges expanded their enrollments.

Columns (5)-(7) in Table 3 report the college value-added estimates on postgraduation employment, using different measures of employment from including nonzero wages only to including employment, graduate studies, and self-employment. The institutional stratification 
in employment persisted during the expansion. The stratified gaps reduced between students in selective institutions and those in less selective institutions, particularly in initial labor market employment (in column 5). Panel (d) of Fig. 3 shows the time-series changes. Consistently with the theoretical framework and numerous anecdotal evidence, students from all types of colleges, except those in four-year newly built colleges, experienced drops in employment in the short term after the expansion policy as it was too short for colleges to invest and adjust for the dramatic enrollment increase (Li et al., 2014).

We also explore the heterogeneity in the estimated college value-added (results are available in an appendix table). Overall, there were no large differences between high SES and low SES students. Nevertheless, if students from low SES background could make their way into the top colleges, they might benefit more than higher SES peers. In contrast, high SES students benefited largely from four-year newly built colleges compared with enrolling at threeyear colleges. Female students were more likely to benefit from attending high-quality colleges, but the gender gap reduced during the expansion period. Finally, engineering-focused colleges across all the institutional selectivity levels had a higher wage premium than nonengineering-focused colleges. This is because engineering-focused colleges have higher average costs and are less likely to expand their enrollment sizes.

We acknowledge several estimation limitations. Potential omitted variable bias might rise as we are not able to control for the College Entrance Exam scores. Using a rich set of pre-college covariates, the identification assumption is to compare students with exactly the same demographics and family background, and studying the same major, but enrolling at different colleges, which might be close-to-random due to the exam score-based admissions and dramatic changes in admission quotas each year. The remaining potential upward bias should be minimal. Furthermore, the key research question is how different types of colleges had stratified production trends. The potential bias needs to be sufficiently large to reverse the conclusions, which is very unlikely. To formally test this argument, we conduct the bounding analysis proposed by Oster (2019) and the results are very robust. Furthermore, results are qualitatively unchanged when we control for college entrance exam scores for the 2003 and 2005 cohorts that we have the relevant information.

\section{Estimating the impacts of expansion on college quality: a natural experiment}

The final analysis is to examine how much the changes in college quality $\gamma_{j t}$ could be causally attributed to the rapid enrollment expansion. Using the exogenous expansion policy as a natural experiment, our research design compares the variations in college quality by college-cohort that faced different degrees of policy-induced enrollment expansion. We estimate the following OLS regression:

$$
\hat{\gamma_{j t}}=\pi * \Delta \text { Enrollment }_{j t}+\lambda * Z_{j t}+v_{j t}
$$

where $\hat{\gamma_{j}}$ are college-cohort value-added estimates from Eq. 2, standardized within the whole college-cohort sample. $\Delta$ Enrollment $_{j t}$ is the relative changes in undergraduate enrollment in college $j$ of cohort $t$ compared with the enrollment of the 1998 cohort. We also add additional controls $Z_{j t}$, including enrollment in 1998, and year and college group fixed effects. We also control for expenditures to test the underlying mechanisms. The identification assumption of $\pi$ is that, conditional on observables, the enrollment change was not associated with other college unmeasured variables that affected college quality. One possible example is that colleges might endogenously set their annual enrollment quotas. However, colleges in China have very little autonomy to change their enrollment plans, 
Table 4 Impacts of enrollment expansion on higher education production (value-added on wage)

\begin{tabular}{|c|c|c|c|c|}
\hline A. Main regressions & (1) & (2) & (3) & (4) \\
\hline$\Delta$ Enrollment & $\begin{array}{l}-0.069^{*} \\
(0.039)\end{array}$ & $\begin{array}{l}-0.202 * * * \\
(0.033)\end{array}$ & $\begin{array}{l}-0.143 * * * \\
(0.037)\end{array}$ & $\begin{array}{l}-0.094 * * * \\
(0.030)\end{array}$ \\
\hline $\ln (\Delta$ Enrollmentin 1998$)$ & & & $\begin{array}{l}0.373 * * * \\
(0.117)\end{array}$ & $\begin{array}{l}-0.194 \\
(0.131)\end{array}$ \\
\hline Year FE & No & Yes & Yes & Yes \\
\hline College group FE & No & No & No & Yes \\
\hline Observations & 154 & 154 & 154 & 154 \\
\hline R-squared & 0.015 & 0.490 & 0.535 & 0.688 \\
\hline B. Mechanisms & (5) & (6) & (7) & (8) \\
\hline$\Delta$ Enrollment & $\begin{array}{l}0.006 \\
(0.034)\end{array}$ & $\begin{array}{l}-0.020 \\
(0.033)\end{array}$ & $\begin{array}{l}0.012 \\
(0.034)\end{array}$ & $\begin{array}{l}0.011 \\
(0.035)\end{array}$ \\
\hline $\ln ($ Operating expenditure $)$ & $\begin{array}{l}0.755^{* * *} \\
(0.120)\end{array}$ & & & $\begin{array}{l}0.382 * * \\
(0.150)\end{array}$ \\
\hline $\ln ($ Personnel expenditure) & & $\begin{array}{l}1.049 * * * \\
(0.149)\end{array}$ & & $\begin{array}{l}0.671 * * * \\
(0.195)\end{array}$ \\
\hline $\ln ($ Total expenditure $)$ & & & $\begin{array}{l}0.936 * * * \\
(0.139)\end{array}$ & \\
\hline C. Heterogeneity & (9) & $(10)$ & (11) & (12) \\
\hline$\Delta$ Enrollment $*$ Top & $\begin{array}{l}0.101 * \\
(0.060)\end{array}$ & $\begin{array}{l}0.057 \\
(0.053)\end{array}$ & & \\
\hline$\Delta$ Enrollment* Elite & $\begin{array}{l}-0.069 \\
(0.057)\end{array}$ & $\begin{array}{l}0.036 \\
(0.053)\end{array}$ & & \\
\hline$\Delta$ Enrollment $* 4 \mathrm{yr}$ (existing) & $\begin{array}{l}-0.193 * * * \\
(0.044)\end{array}$ & $\begin{array}{l}-0.031 \\
(0.040)\end{array}$ & & \\
\hline$\Delta$ Enrollment $* 4 \mathrm{yr}$ (new) & $\begin{array}{l}-0.160 * * * \\
(0.044)\end{array}$ & $\begin{array}{l}0.008 \\
(0.041)\end{array}$ & & \\
\hline$\Delta$ Enrollment $*$ Vocational & $\begin{array}{l}-0.178 * * * \\
(0.050)\end{array}$ & $\begin{array}{l}0.013 \\
(0.052)\end{array}$ & & \\
\hline$\Delta$ Enrollment $*$ Non-engineering & & & $\begin{array}{l}-0.132 * * * \\
(0.036)\end{array}$ & $\begin{array}{l}0.014 \\
(0.035)\end{array}$ \\
\hline$\Delta$ Enrollment $*$ Engineering & & & $\begin{array}{l}-0.185^{* * * *} \\
(0.047)\end{array}$ & $\begin{array}{l}-0.006 \\
(0.043)\end{array}$ \\
\hline Expenditures & No & Yes & No & Yes \\
\hline
\end{tabular}

This table presents OLS regression estimates on the impacts of enrollment expansion on college valueadded during 1999-2013. College value-added measures are estimated from an OLS regression with college-year fixed effects and the full controls in columns 4 of Table 3 (the five groups and interactions with linear trends are excluded). $\Delta$ Enrollmentis the relative change of undergraduate enrollment in the year of graduation compared with that in year 1998 (=1 indicates $100 \%$ increase). Year fixed effects and enrollment in 1998 are included in Columns (5)-(12). Robust standard errors are in parentheses. * significant at 10\%; $* *$ significant at $5 \%$; *** significant at $1 \%$

which are determined by the Ministry of Education and state-level Department of Education. Furthermore, as a national policy, the expansion policy was implemented so dramatically and unpredictably that colleges could not endogenously respond to the policy changes. We have matched 154 college-year observations in the estimated college quality 
$\gamma_{j t}$ and spending data. The unmatched cases are mostly due to non-reporting in the spending data, particularly in the early years. However, we don't find systematically non-random unmatch problems.

Column (1) of Panel A in Table 4 examines the raw correlation between enrollment expansion and the estimated college value-added on the outcome of initial wages, which suggests that college quality was negatively correlated with the increase in undergraduate enrollment. Results on other value-added outcomes and using different measures of the enrollment expansion are quite consistent that we do not report all of those estimates due to the page limit. Without controlling for any other covariates, each $100 \%$ increase in undergraduate enrollment from 1998 is associated with a 0.069 standard deviations decrease in college quality. The estimated negative impact of enrollment expansion enlarges and becomes statistically significant when we exclude differences between years in Column (2).

Column (3) uses our preferred specification that controls for year fixed effects and the original college size in 1998. Results show that each $100 \%$ increase in undergraduate enrollment from 1999 decreases college value-added on wages by about 0.143 standard deviations. Since the average college size nearly tripled as shown in Table 1, the results imply that the average college quality would drop by about 0.43 standard deviations if there were no complementary investments in higher education. The estimates are qualitatively unchanged when we compare colleges within institutional stratification in Column (4).

We further examine how inputs in higher education mitigate the negative shocks of expansion on college quality in Panel B. All the specifications control for enrollment in 1998 and year fixed effects as in Column (3). Results in Columns (5)-(8) consistently show that the impact of enrollment expansion could be fully compensated by the increased investment, particularly the investment in faculty. For example, Column (6) suggests that each $100 \%$ increase in personnel expenditure per student - capturing both quantity and quality of faculty resources - is statistically significantly associated with a 0.755 standard deviations increase in college quality. Note that this is not a causal estimate since the spending might be correlated with unobservables. Holding per-student personnel spending equal, enrollment expansion did not affect college quality at all. Column (8) shows that investment in faculty is far more important than investment in operation to have impacted college quality, although the correlation coefficient of the two variables is $91 \%$.

We have presented compelling evidence that the enrollment expansion might not negatively affect college quality if the college investments (especially in faculty resources) kept the same pace. However, as we show earlier that many colleges were limited to increase such investments, and the public funding has been concentrated on the selective institutions in China (Wang, 2014; Yang \& Wang, 2020), the increase in enrollment and the differential college investments might have contributed to the expanding stratification in higher education. In Panel C, we explore the differential changes across college selectivity levels. To ease comparison, we report the main effects for each college group rather than interaction terms. Column (9) shows that the enrollment expansion had much larger negative impacts on less selective colleges. This college stratification gap could be nearly explained by the resource gap, as suggested by the results in Column (10). If less selective colleges had the same increases in inputs, the enrollment expansion would not have largely reduced the college quality. Column (11) shows that the marginal effect was about $40 \%$ larger in engineeringfocused colleges than that in non-engineering-focused colleges. Similarly, holding college investments equal, the negative shocks by enrollment expansion were fully compensated.

Our analyses have limitations. First, as the National Survey on College Graduates' Employment changed the survey institutions each year, we cannot use a college-cohort 
panel data that further eliminate time-invariant factors. An alternative approach is to collapse data to college type-cohort and estimate a panel data fixed effects model. Estimates are similar but under-powered due to the small number of observations. Second, we can only observe a student's initial wage. Different colleges may have different value-added on wage growth (Thomas \& Zhang, 2005). However, entry conditions (e.g., initial earnings) have lasting impacts on long-term career success (Oyer, 2006; Altonji et al., 2016). Future research can look at these long-term impacts.

\section{Discussion and conclusion}

Over the past decades, enrollment expansion has been an important, common national policy to increase access to higher education opportunities all over the world. A key question among researchers, policymakers, and practitioners is whether and how expansion affects inequality in the access to higher education as well as the production of higher education (Arum et al., 2007). Using unique institution-level and student-level data, this paper presents new evidence on how expansion affects access, resources, and production of higher education by studying the dramatic higher education expansion in China from 1999 to 2012.

Similar to the higher education expansion experiences in many other countries, higher education expansion in China creates new college opportunities but does not reduce the inequality in the access to (elite) college. Students from high SES families are persistently at an advantage in college opportunities. Moreover, expansion is often accompanied by differentiation and stratification of higher education institutions. Without sufficient per-student investments and resources, particularly in less selective colleges, expanding enrollment may have diminished a college's value-added quality. The policy practice in China shows that the inequality in access between high- and low-SES students and the stratified production between colleges persisted or even enlarged during the dramatic expansions.

These findings have important policy implications. Colleges have long been seen as "the great equalizer," which motivates the policy option that an expansion in higher education would promote social mobility. However, simply expanding the pool of college students is unlikely to boost intergenerational income mobility (Zhou, 2019). Our findings of the unequal access to elite colleges during the expansion policy are consistent with studies conducted by other Chinese scholars using various data sources and methods, including Liu (2006) using the Chinese General Social Survey (CGSS) data of 2003, Ding (2007) using data from urban household surveys conducted by the National Statistics Bureau of China in 1991 and 2000, Li (2010) using 1\% census data in 2005, Ye and Ding (2015) using data from college student survey in Beijing in 2011, and Luo et al. (2018) using the 2012 China College Student Survey. The persisting and expanding gap in the access to elite college opportunities suggests that students from low SES families may not have fully benefited from the expansion policy. Other college-enrollment policies should be considered in order to expand college opportunities, including promoting academic preparation in K-12 school period, expanding financial aid, and providing information and guidance in college applications (Perna et al., 2008; Page $\&$ Scott-Clayton, 2016). In recent years, China has been implementing special affirmative action programs for rural students in low-income regions that have the potential to expand elite higher education opportunities for those disadvantaged students.

Beyond access, for those students who have already made their way into selective institutions, the possible diminished value of college induced by enrollment expansion may 
reduce college premiums in labor market outcomes. In this paper, we have shown that expanding enrollment without sufficient per-student resources would have harmed college quality and therefore student outcomes. In response to the possible negative impacts of college production, China ended the expansion policy in 2012 in order to "improve higher education quality." Two years later, the Chinese Ministry of Education decided to re-structure the higher education with a focus on shifting more than 600 local four-year colleges to "modern vocational education," most of which are newly built colleges during the expansion policy. These policy changes are consistent with the implications in this paper: Policymakers and college administrators have to make sure that institutional resources per student (e.g., faculty and facility) will not decline during enrollment expansion (Bound \& Turner, 2007; Bound et al., 2010).

In the most recent years, China has been using the expansion policy again to mitigate the supply pressures in the labor market. The three-year vocational colleges expanded enrollment by 1.16 million in 2019 and will increase enrollment by another 2 million in the next two years. Graduate programs also expanded enrollment by 189,000 in 2020 in response to the COVID-19 pandemic. While both expansion policies mentioned "qualitative expansion" that implies a series of policies would be used to ensure that the higher education quality will not decline, future research is needed to evaluate how these new expansion policies will affect Chinese higher education.

Finally, from the international comparative perspective, lessons from the Chinese higher education expansion show that simply expanding higher education enrollment is not an optimal development strategy and will not solve the unequal college access problem. Rather, without complementary policies and inputs, there are likely widened SES gaps in access and decreased college production. Moreover, the expansion of higher education in both developed and developing countries has been changing the landscape of global higher education market. In particular, colleges in developed countries are competing heavily for international students from developing countries (Chellaraj et al., 2005; Freeman, 2010; Bound et al., 2016). Future work is needed to examine how the worldwide enrollment expansion affects the supply and demand in the global higher education market.

\section{References}

Alon, S. (2009). The evolution of class inequality in higher education: Competition, exclusion, and adaptation. American Sociological Review, 74(5), 731-755.

Altonji, J. G., Kahn, L. B., \& Speer, J. D. (2016). Cashier or consultant? Entry labor market conditions, field of study, and career success. Journal of Labor Economics, 34(S1), S361-S401.

Arum, R., Gamoran, A., \& Shavit, Y. (2007). More inclusion than diversion: Expansion, differentiation, and market structure in higher education. In Y. Shavit, R. Arum, and A. Gamoran, editors, Stratification in Higher Education: A Comparative Study. Stanford University Press.

Barr, A., \& Turner, S. E. (2013). Expanding enrollments and contracting state budgets: The effect of the Great Recession on higher education. The ANNALS of the American Academy of Political and Social Science, 650(1), 168-193.

Bianchi, N. (2019). The indirect effects of educational expansions: Evidence from a large enrollment increase in university majors. Journal of Labor Economics, forthcoming.

Black, D. A., \& Smith, J. A. (2004). How robust is the evidence on the effects of college quality? Evidence from matching. Journal of Econometrics, 121(1), 99-124.

Black, D. A., \& Smith, J. A. (2006). Estimating the returns to college quality with multiple proxies for quality. Journal of Labor Economics, 24(3), 701-728.

Boliver, V. (2011). Expansion, differentiation, and the persistence of social class inequalities in British higher education. Higher Education, 61(3), 229-242. 
Borgen, N. T. (2014). College quality and hourly wages: Evidence from the self-revelation model, sibling models and instrumental variables. Social Science Research, 48, 121-134.

Bound, J., Braga, B., Khanna, G., \& Turner, S. (2016). A passage to America: University funding and international students. National Bureau of Economic Research: Technical report.

Bound, J., Lovenheim, M. F., \& Turner, S. (2010). Why have college completion rates declined? An analysis of changing student preparation and collegiate resources. American Economic Journal: Applied Economics, 2(3), 129-57.

Bound, J., \& Turner, S. (2007). Cohort crowding: How resources affect collegiate attainment. Journal of Public Economics, 91(5-6), 877-899.

Bratti, M., Checchi, D., \& De Blasio, G. (2008). Does the expansion of higher education increase the equality of educational opportunities? Evidence from Italy. Labour, 22(s1), 53-88.

Brewer, D. J., Eide, E. R., \& Ehrenberg, R. G. (1999). Does it pay to attend an elite private college? Journal of Human Resources, 34(1), 104-123.

Carnoy, M., Loyalka, P., Dobryakova, M., Dossani, R., Kuhns, K., Wang, R., et al. (2013). University expansion in a changing global economy: Triumph of the BRICs?. Stanford University Press.

Chellaraj, G., Maskus, K. E., \& Mattoo, A. (2005). The contribution of skilled immigration and international graduate students to US innovation. The World Bank.

Chetty, R., Friedman, J., Saez, E., Turner, N., \& Yagan, D. (2017). Mobility report cards: The role of colleges in intergenerational mobility. NBER Working Paper, (w23618).

Chetty, R., Friedman, J. N., \& Rockoff, J. E. (2014a). Measuring the impacts of teachers I: Evaluating bias in teacher value-added estimates. American Economic Review, 104(9), 2633-2379.

Cunha, J. M., \& Miller, T. (2014). Measuring value-added in higher education: Possibilities and limitations in the use of administrative data. Economics of Education Review, 42, 64-77.

Dale, S., \& Krueger, A. B. (2014). Estimating the return to college selectivity over the career using administrative earnings data. Journal of Human Resources, 49(3), 323-358.

Dale, S. B., \& Krueger, A. B. (2002). Estimating the payoff to attending a more selective college: An application of selection on observables and unobservables. The Quarterly Journal of Economics, 117(4), 1491-1527.

Deer, C. (2005). Higher education access and expansion: The French experience. Higher Education Quarterly, 59(3), 230-241.

DesJardins, S. L., \& Toutkoushian, R. K. (2005). Are students really rational? The development of rational thought and its application to student choice. In Higher Education: Handbook of Theory and Research, pages 191-240. Springer.

Devereux, P. J., \& Fan, W. (2011). Earnings returns to the British education expansion. Economics of Education Review, 30(6), 1153-1166.

Dias, D., Marinho-Araujo, C., Almeida, L., \& Amaral, A. (2011). The democratisation of access and success in higher education. Higher Education Management and Policy, 23(1), 1-20.

Ding, X. (2007). Expansion and equality of access to higher education in China. Frontiers of Education in China, 2(2), 151-162.

Freeman, R. B. (2010). What does global expansion of higher education mean for the United States? In American Universities in a Global Market, pages 373-404. University of Chicago Press.

Gaertner, M. N., Kim, J., DesJardins, S. L., \& McClarty, K. L. (2014). Preparing students for college and careers: The causal role of Algebra II. Research in Higher Education, 55(2), 143-165.

Ha, W., Kang, L., \& Song, Y. (2020). College matching mechanisms and matching stability: Evidence from a natural experiment in China. Journal of Economic Behavior \& Organization, 175, 206-226.

Hanushek, E. A., \& Rivkin, S. G. (2010). Generalizations about using value-added measures of teacher quality. American Economic Review, 100(2), 267-271.

Hemelt, S. W., Stange, K. M., Furquim, F., Simon, A., \& Sawyer, J. E. (2020). Why is math cheaper than English? Understanding cost differences in higher education. Journal of Labor Economics, forthcoming.

Hillman, N. W. (2016). Geography of college opportunity: The case of education deserts. American Educational Research Journal, 53(4), 987-1021.

Hout, M. (2012). Social and economic returns to college education in the United States. Annual Review of Sociology, 38, 379-400.

Hoxby, C., Avery, C., et al. (2013). The missing "one-offs": The hidden supply of high-achieving, lowincome students. Brookings Papers on Economic Activity, 44(1(Spring)):1-65.

Hoxby, C. M. (2009). The changing selectivity of American colleges. Journal of Economic Perspectives, 23(4), 95-118.

Juhn, C., Kim, D. I., \& Vella, F. (2005). The expansion of college education in the United States: Is there evidence of declining cohort quality? Economic Inquiry, 43(2), 303-315.

Kyui, N. (2016). Expansion of higher education, employment and wages: Evidence from the Russian transition. Labour Economics, 39, 68-87. 
Kyvik, S. (2008). The dynamics of change in higher education: Expansion and contraction in an organisational field (Vol. 27). Springer.

Levin, H. M. \& Xu, Z. (2005). Issues in the expansion of higher education in the people's republic of China. China Review, pages 33-59.

Li, C. (2010). Expansion of higher education and inequality in opportunity of education: A study on effect of "kuozhao" policy on equalization of educational attainment. Sociological Studies, 3, 82-113.

Li, H., Loyalka, P., Rozelle, S., Wu, B., \& Xie, J. (2015). Unequal access to college in china: How far have poor, rural students been left behind? The China Quarterly, 221, 185-207.

Li, H., Ma, Y., Meng, L., Qiao, X., \& Shi, X. (2017). Skill complementarities and returns to higher education: Evidence from college enrollment expansion in China. China Economic Review, 46, 10-26.

Li, L. (2004). China's higher education reform 1998-2003: A summary. Asia Pacific Education Review, $5(1), 14-22$.

Li, S., Whalley, J., \& Xing, C. (2014). China's higher education expansion and unemployment of college graduates. China Economic Review, 30, 567-582.

Liu, J. (2006). Expansion of higher education in china and inequality in entrance opportunities: 1978-2003. Chinese Journal of Sociology, 3, 158-179.

Long, M. C. (2010). Changes in the returns to education and college quality. Economics of Education Review, 29(3), 338-347.

Lucas, S. R. (2001). Effectively maintained inequality: Education transitions, track mobility, and social background effects. American Journal of Sociology, 106(6), 1642-1690.

Luo, Y., Guo, F., \& Shi, J. (2018). Expansion and inequality of higher education in China: How likely would Chinese poor students get to success? Higher Education Research \& Development, 37(5), 1015-1034.

Manski, C. F., Wise, D. A., \& Wise, D. A. (1983). College choice in America. Harvard University Press.

Marginson, S. (2016a). High participation systems of higher education. The Journal of Higher Education, 87(2), 243-271.

McCowan, T. (2007). Expansion without equity: An analysis of current policy on access to higher education in Brazil. Higher education, 53(5), 579-598.

McCoy, S., \& Smyth, E. (2011). Higher education expansion and differentiation in the Republic of Ireland. Higher Education, 61(3), 243-260.

Oppedisano, V. (2011). The (adverse) effects of expanding higher education: Evidence from Italy. Economics of Education Review, 30(5), 997-1008.

Oster, E. (2019). Unobservable selection and coefficient stability: Theory and evidence. Journal of Business \& Economic Statistics, 37(2), 187-204.

Ou, D., \& Hou, Y. (2019). Bigger pie, bigger slice? The impact of higher education expansion on educational opportunity in China. Research in Higher Education, 60(3), 358-391.

Oyer, P. (2006). Initial labor market conditions and long-term outcomes for economists. Journal of Economic Perspectives, 20(3), 143-160.

Özoğlu, M., Gür, B. S., \& Gümüs, S. (2016). Rapid expansion of higher education in Turkey: The challenges of recently established public universities (2006-2013). Higher Education Policy, 29(1), 21-39.

Page, L. C., \& Scott-Clayton, J. (2016). Improving college access in the united states: Barriers and policy responses. Economics of Education Review, 51, 4-22.

Perna, L. W. (2006). Studying college access and choice: A proposed conceptual model. In Higher Education: Handbook of Theory and Research, pages 99-157. Springer.

Perna, L. W., Rowan-Kenyon, H., Bell, A., Thomas, S. L., \& Li, C. (2008). A typology of federal and state programs designed to promote college enrollment. The Journal of Higher Education, 79(3), 243-267.

Perna, L. W., \& Titus, M. A. (2004). Understanding differences in the choice of college attended: The role of state public policies. The Review of Higher Education, 27(4), 501-525.

Posselt, J. R., \& Grodsky, E. (2017). Graduate education and social stratification. Annual Review of Sociology, 43, 353-378.

Raftery, A. E., \& Hout, M. (1993). Maximally maintained inequality: Expansion, reform, and opportunity in Irish education, 1921-75. Sociology of Education, pages 41-62.

Reimer, D., \& Pollak, R. (2010). Educational expansion and its consequences for vertical and horizontal inequalities in access to higher education in West Germany. European Sociological Review, 26(4), 415-430.

Rodriguez, A., Furquim, F., \& DesJardins, S. L. (2018). Categorical and limited dependent variable modeling in higher education. In Higher Education: Handbook of Theory and Research, pages 295-370. Springer.

Schofer, E., \& Meyer, J. W. (2005). The worldwide expansion of higher education in the twentieth century. American Sociological Review, 70(6), 898-920.

Shavit, Y., Arum, R., \& Gamoran, A. (2007). Stratification in Higher Education: A Comparative Study. Stanford University Press. 
Soliz, A. (2018). The effects of the expansion of for-profit colleges on student enrollments and outcomes at community colleges. Educational Evaluation and Policy Analysis, 40(4), 631-652.

Stapleton, D. C., \& Young, D. J. (1988). Educational attainment and cohort size. Journal of Labor Economics, 6(3), 330-361.

Taubman, P., Wales, T. et al. (1972). Mental ability and higher educational attainment in the 20th century. NBER Books.

Teranishi, R. T., Ceja, M., Antonio, A. L., Allen, W. R., \& McDonough, P. M. (2004). The college-choice process for Asian Pacific Americans: Ethnicity and socioeconomic class in context. The Review of Higher Education, 27(4), 527-551.

Thomas, S. L., \& Zhang, L. (2005). Post-baccalaureate wage growth within four years of graduation: The effects of college quality and college major. Research in Higher Education, 46(4), 437-459.

Trow, M. (1972). The expansion and transformation of higher education. International Review of Education, $18(1), 61-84$.

Trow, M. A. (1976). Problems in the Transition from Elite to Mass Higher Education. Institute of International Studies: University of California.

Walker, I., \& Zhu, Y. (2008). The college wage premium and the expansion of higher education in the UK. The Scandinavian Journal of Economics, 110(4), 695-709.

Walters, P. B. (1984). Occupational and labor market effects on secondary and postsecondary educational expansion in the United States: 1922 to 1979. American Sociological Review, 49(5), 659-671.

Wan, Y. (2006). Expansion of Chinese higher education since 1998: Its causes and outcomes. Asia Pacific Education Review, 7(1), 19-32.

Wang, Q. (2014). Crisis management, regime survival and guerrilla-style policy-making: The June 1999 decision to radically expand higher education in China. The China Journal, 71, 132-152.

Wang, R. (2014). The commanding heights: The state and higher education in China. In S. Fan et al, editor, The Oxford Companion to the Economics of China, pages 472-477. Oxford University Press.

Weisbrod, B. A., \& Karpoff, P. (1968). Monetary returns to college education, student ability, and college quality. The Review of Economics and Statistics, 50(4), 491-497.

Wells, R. S., \& Lynch, C. M. (2012). Delayed college entry and the socioeconomic gap: Examining the roles of student plans, family income, parental education, and parental occupation. The Journal of Higher Education, 83(5), 671-697.

Wu, X. (2019). Inequality and social stratification in postsocialist China. Annual Review of Sociology, 45(363-382).

Yang, P. (2010). Who gets more financial aid in China? A multilevel analysis. International Journal of Educational Development, 30(6), 560-569.

Yang, P., \& Wang, R. (2020). Central-local relations and higher education stratification in China. Higher Education, 79(1), 111-139.

Ye, X. (2018). Improving college choice for the poorest students: Results from randomized experiments in centralized admissions. Working Paper.

Ye, X., \& Ding, Y. (2015). Expanding chinese higher education: Quality and social stratification. Chinese Journal of Sociology, 35(03), 193-220.

Yeung, W.-J. J. (2013). Higher education expansion and social stratification in China. Chinese Sociological Review, 45(4), 54-80.

Yue, C. (2015). Expansion and equality in Chinese higher education. International Journal of Educational Development, 40, 50-58.

Zhang, L. (2005). Advance to graduate education: The effect of college quality and undergraduate majors. The Review of Higher Education, 28(3), 313-338.

Zhang, L. (2005). Do measures of college quality matter? The effect of college quality on graduates' earnings. The Review of Higher Education, 28(4), 571-596.

Zhou, M., \& Hill, A. (2009). Affirmative action in China and the US: A dialogue on inequality and minority education. Springer.

Zhou, X. (2019). Equalization or selection? Reassessing the meritocratic power of a college degree in intergenerational income mobility. American Sociological Review, 84(3), 459-485.

Publisher's Note Springer Nature remains neutral with regard to jurisdictional claims in published maps and institutional affiliations. 